\title{
Falsification of Financial Statements: Historical and Evolutionary Aspect
}

\author{
Kulikova L.I.
}

\section{Gafieva G.M.}

Kazan Federal University, Institute of Management, Economics and Finance, Kazan, 420008, Russia

\section{Doi:10.5901/mjss.2014.v5n24p41}

\section{Abstract}

Both Russian and foreign researchers devote their studies to the nature of falsification of financial statements. This subject was under interest of Russian accounting specialists since the beginning of the XX century. Therefore, the objective of the paper was to track historical development of the notion of financial statement falsification and its definition. This improves our understanding of falsification methods and helps to throw light to ways to prevent it.

Keywords: financial statement, falsification, balance sheet

\section{Introduction}

Various representatives of Russian and foreign accounting schools differently understood the nature of veiling and falsification of financial statements. N. S. Arinushkin narrowed a falsification problem to balance sheet and the misstatement of its items (Arinushkin, 1927). I.R. Nikolaev considered that falsification of the reporting is a consequence of various approaches to valuation of assets (Nikolaev, 1926). Ya.M. Galperin noted that falsification represents the distortion of balance sheet resulting in changes in the material contents of accounts and groups of balance sheet items (Galperin, 1925). N. R. Weizman believed that falsification is a consequence of an intention to hide business information (Weizman, 1927). I.F. Sherr claimed that falsification of the reporting is directed on distortion of a condition and a size of property and profitability of a company (Sherr, 1926). N.A. Kiparisov understood distortion of the material content of balance sheet which leads to misstatement of financial results of business activity of a company as a falsification (Kiparisov, 1928). According to Ya.V. Sokolov, falsification of the reporting are put into practices by a company's management intentionally (Sokolov, 2000). This illustrates that there was diversity of definitions of falsification of financial statement. Therefore, there was no uniform understanding of its causes and consequences. This led to the difference in the suggested methods of detection of the falsification and its prevention. With modern methods being the development of earlier ideas, it is important to study the evolution of falsification concept to understand purpose and limitations of those methods.

\section{Materials and Methods}

For reaching this objective, archive books and materials have been studied in detail. All collected definitions were analyzed and classified.

\section{Results and Discussion}

Some specialist, like N. S. Arinushkin, connected falsification with clarity and truthfulness of the balance sheet. Under clarity he understood understandability and presentation of financial statement in an easy to read manner, and also each "part of balance" to be congruent to its economic nature. The truthfulness of the balance sheet means that it is free from falsifications (Arinushkin, 1927).

In 1925 in the book "Basics of accounting study" (Galperin, 1925) Russian accounting specialist Ya.M. Galperin defined two main types of violation of truthfulness of the balance sheet:

a) violation of truthfulness of the balance sheet, which affects its structure;

b) violation of truthfulness of the balance sheet, which affects its quantitative estimates.

He called the first type of violations blackout, or balance sheet veiling, and the second type of violations - a 
perversion, or balance sheet falsification. Ya.M. Galperin considered that in case of veiling of the balance sheet there is an opportunity to find a mistake, whilst in case of falsification this opportunity is considerably lower. Ya.M. Galperin believed that "falsification of the balance sheet leads to the presentation of a wrong balance sheet in its essence, which changes content and valuation of its elements".

The Swiss professor I.F. Sherr in 1926 in his work "Accounting and balance sheet" (Sherr, 1926) highlighted the need "of bringing to the light the secrets of the balance preparators, putting to themselves a task, because of different incentives, to present in the best or worst way companies' position, conditions and the value of a property and its profitability".

I.F. Sherr understood as veiling of a balance sheet "such form of preparation of a balance sheet that makes the economic facts not clear or difficult to understand so the picture of financial position of the company is inaccurate or wrong". He identifies formal and material means of veiling. Balance sheet veiling Sherr I.F. considered as an instrument of business policy of joint-stock companies.

The German accounting specialist of that time P. Gerstner in 1926 in his book "Balance sheet analysis" (Gerstner, 1926) proved the requirement to publish a balance sheet to be a reason of its veiling. In his opinion, those who prepare published balances sheet use "different tricks, like shift of items, aggregation of several items to one, special not clear designations, not to mention possible obscuration or even fakes" ("a coloring, a combing, a balance waving" are also noted as ways of veiling of the balance sheet).

In 1931 well-known Russian accounting study specialist N.A. Blatov in the book "Accounting study" (Blatov, 1931), describing rules of balance sheet preparation, notes that violations of balance sheet preparation requirements leads to veiling and falsification of balance sheet. Besides "veiling sometimes happens unintentionally, because of ignorance or negligence of those who prepare balance sheet". However, intentional veiling cases are not rare - it is when "veil" is thrown on unattractive parts of the balance sheet to be hidden from public gaze. Falsification is defined as "violation of the requirement of accuracy, truthfulness of balance sheet; becoming incorrect, the balance sheet represents distortion, fake, falsification of the actual, correct balance sheet by its invaluable substitute. Falsification always happens deliberate, and the forged balance represents a balance sheet crime".

N.A. Blatov considered that it is difficult to draw clear, certain line between the concepts "veiling" and "falsification": "deliberate veiling is very close to falsification, and any falsification, of course, does balance sheet not clear, veils it".

In 1927 in N. R. Weizman's book "Accounting study course" (Weizman, 1927) the whole chapter is devoted to the questions of falsification and veiling of balances sheet. He understood the wrong aggregation of balance sheet items as veiling of balance sheet, "being reflected in clarity of balance sheet, but not causing any changes in the profit (loss) or capital of a company". Falsification, according to N. R. Weizman, represents violation of reality of an asset and a passive, almost always resulting in a wrong bottom line figure.

According to N. R. Weizman, receivables in a balance sheet is the most vulnerable item for all kinds of falsification, because valuation or doubtfulness of receivables from the third parties almost always depends on a judgment of a company itself. Among receivables items special attention should be paid to "other receivables" where many doubtful and disputable amounts can be hidden very often.

In work of leading Russian accounting specialist N.A.Kiparisov "Accounting study basics. Preparation of balance sheet and its analyses", written in 1928 (Kiparisov, 1928), it was noted that it is quite difficult to differentiate "veiling" and "falsification" concepts, because any blackout of a balance sheet is already its misstatement, but nevertheless some difference between these two concepts can be found. "Veiling, or balance sheet blackout, is used to hide in balance some parties of economic activity or some shades of economic position, but doesn't affect net profit and amount of capital. Falsification of a balance sheet assumes misstatement of its material content, which often leads to distortion of the results reached by a company" Furthermore N.A. Kiparisov distinguished two types of balance sheet falsification: falsification resulting in misrepresentation of balance sheet by making wrong entries, but without affecting financial results, and falsification of results and capital of a company.

Professor Ya.V. Sokolov in 2000 introduced the idea that it is impossible to achieve exact reflection of economic activities in financial statement preparation and therefore companies use veiling and falsification tricks (Sokolov, 2000). According to Ya.V. Sokolov, "if requirements of normative documents are fulfilled, but the absolute truth after all isn't reached, it is said about reporting veiling ... If applied accounting techniques are beyond the rules, set by normative documents, in that case it is reporting falsification".

\section{Conclusion}

The analysis of professional views on the nature of falsification of financial statements showed that it is one of the 
accounting problems that have been understood differently through the time. There was no one exact definition for financial statement falsification and therefore different approaches were suggested for preventing it.

\section{References}

Arinushkin, N. S., 1927. Accounting study, Samara, p: 47

Blatov, N.A., 1931. Accounting study. 3d edition State trade publishing house, Moscow. p:134

Galperin, Ya.M., 1925. Basics of accounting study. The edition of practical institute of bookkeeping of G. Zinovyev, Tiflis. p:325

Gerstner, P., 1926. Balance sheet analysis.Economic life, Moscow. p:52

Kiparisov, N.A., 1928. Accounting study basics. Preparation of balance sheet and its analyses. Publishing house of trade commetee of USSR and RSFSR. pp:126-127

Marchenko, A.K, Barabanov, I.M, 1980. Basics of accounting. Finance, Moscow. p:58

Nasarov, D.V., Medvedev, M.U., 2006. Anthology of accounting thought. Accounting history. Economist, Moscow. p: 267

Nikolaev, I.R. 1926. Problem of reality of the balance. Economic education, Leningrad. p:51

Sherr, I.F., 1926. Accounting and balance sheet. Economy and Life, Moscow. p:456

Sokolov, Ya.V., 2000. Basics of accounting. Finance and statistics, Moscow. p:384

Weizman, N. R, 1927. Accounting study course. Tsentrosoyuz, Moscow. p:205.

Kumara Swamy, M.R. (2014). Case studies of corporate misgovernance: A new approach to financial statement analysis. International Journal of Business, 19 (1), pp. 99-112

Hein, J., Zobrist, R., Konrad, C.,Schuepfer, G. (2012). Scientific fraud in 20 falsified anesthesia papers: Detection using financial auditing methods. Anaesthesist, 61 (6), pp. 543-549.

Rollins, T.P., Bremser, W.G. (1997). The SEC's enforcement actions against auditors: An auditor reputation and institutional theory perspective. Critical Perspectives on Accounting, 8 (3), pp. 191-206 